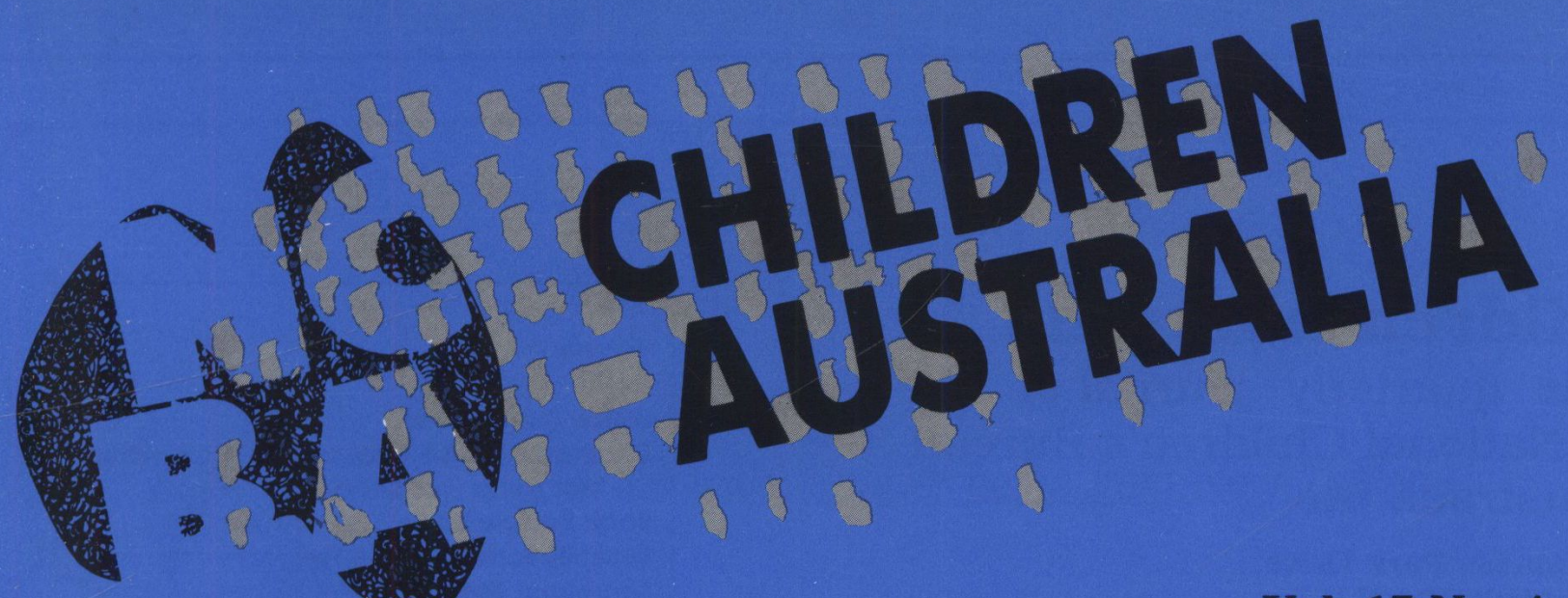

Vol. 17 No. 4, 1992

Registered by Australia Post Publication No. VAW 4651. ISSN 1035-0772

\title{
MATERNAL
} STRESS
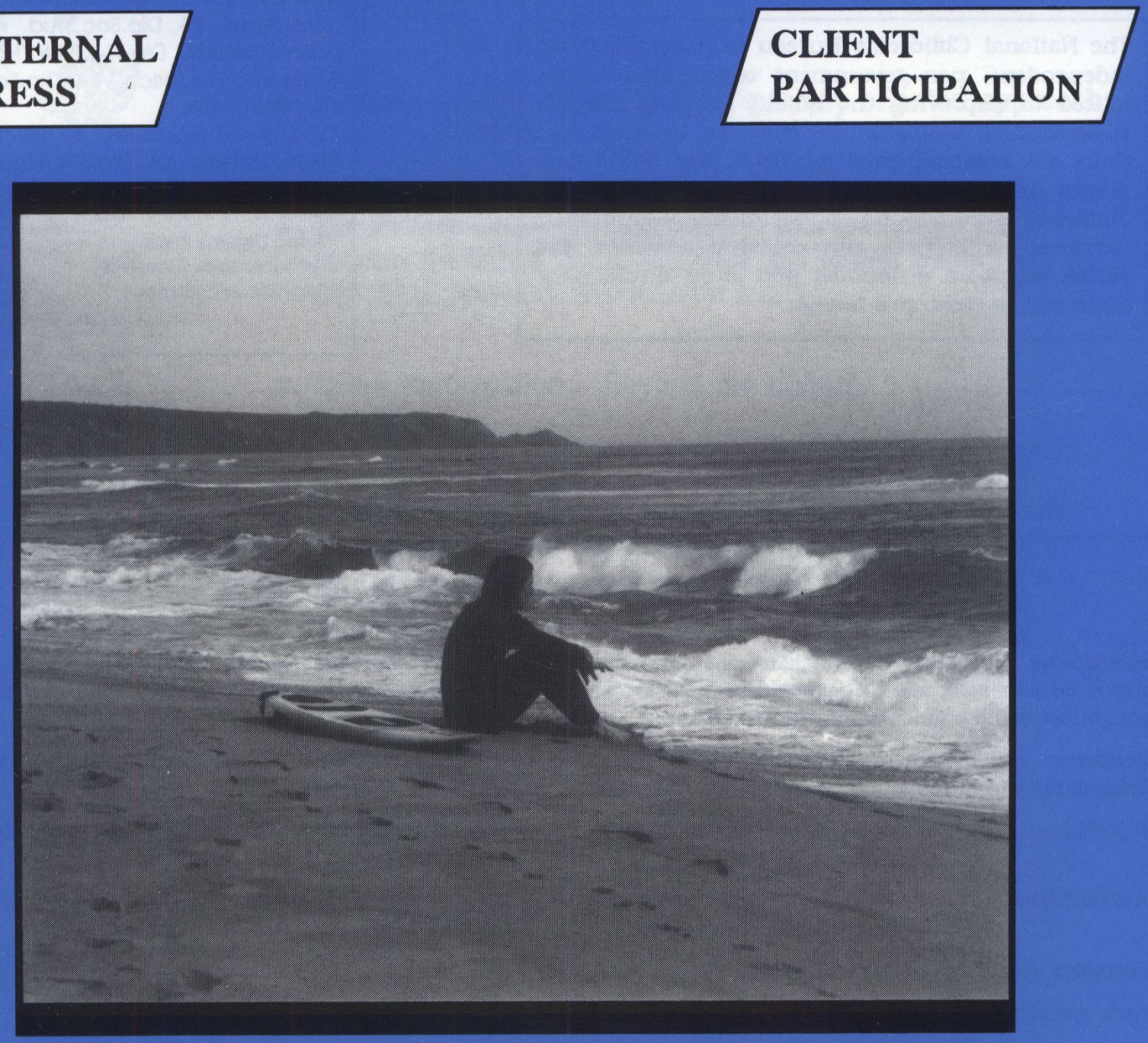

\section{JUVENILE JUSTICE} IN NEW ZEALAND

\section{FAMILY GROUP CONFERENCES}

THE NATIONAL CHILDREN'S BUREAU OF AUSTRALIA

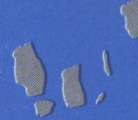
8\{

(1)

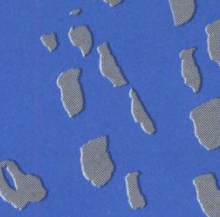




\section{Children Australia}

\section{is the quarterly journal of The National Children's Bureau of Australia Inc.}

19 Business Park Drive, Notting Hill, Vic. 3168

PO Box 686, Mulgrave, Vic. 3170

Tel: (03) 5589100 Fax (03) 5589243

The National Children's Bureau of Australia is an independent, non-government organisation committed to improving the quality of care and life opportunitles avallable to children in Australia. Since its establishment in 1971, the NCBA has played an important advocacy role in support of chlldren. Through its publications, Information Services, conferences and research activities, the NCBA promotes a national and mult-disciplinary approach to chlldren's issues.
Volume 17, No.4

Editor. Lloyd Owen

Chairman, NCBA Publications Committee:

Margarita Frederico

Book Revlew Editor. June Allan

Subscriptions: Larraine Redshaw

Secretary: Maureen Himbury

Layout and Production:

Loulse Riordan Pitcher

The National Children's Bureau of

Australla Inc. Publications Committee

June Allan, BA, Dlp.Soc.Stud.

John Edwards, Dip.YL., BSW (Hons), MSW.

Margarita Frederico, BA. Dip.Soc.Stud.,

MSW, MBA.

Christopher Goddard, BA (Hons), MSW.

Denis Oakley, BA, Dip.Soc.Stud.

Lloyd Owen, BA, Dlp.Soc.Stud., MSW.

Printer: Llenless Press

Cartoons: Jock MacNeish

Graphics: Jeff Gimour

\section{NOTES TO CONTRIBUTORS}

1. Manuscripts should be typewritten on one side only on A4 paper, with double spacing and wide margins. Three hard copies should be submitted, and the approximate number of words stated. Wherever possible, material should also be submitted on IBM compatible diskette (5.25 or 3.5$)$ in ASCII format.

2. References should be referred to in the text by giving, in brackets, the surname of the author and should be listed in alphabetical order at the end of the article as follows:

BOOKS: $\quad$ Author's name and initials; year of publication in brackets; title of book (in italics); publisher; page reference if appropriate.

ARTICLES: $\quad$ Author's name and initials; date of publication in brackets; title of article; abbreviated title of journal (in italics); volume and number.

3. Footnotes should be kept to a minimum.

4. Each article should be prefaced with a brief resume.

5. Contributors are invited to submit a brief biographical note and a current photograph suitable for printing.

6. All manuscripts submitted will be reviewed by three referees. Manuscripts may be accepted for publication, returned for revision or rejected. The Editor's decision is final.

7. All manuscripts and editorial communications should be addressed to:

The Editor, Children Australia

c/- Department of Social Work

La Trobe University

Plenty Road, Bundoora, Vic 3083

All book reviews should be addressed to: The Book Review Editor, at the above address.

8. All rights of reproduction are strictly reserved. 
VOLUME 17, NO. 4, 1992

Editor: Lloyd Owen

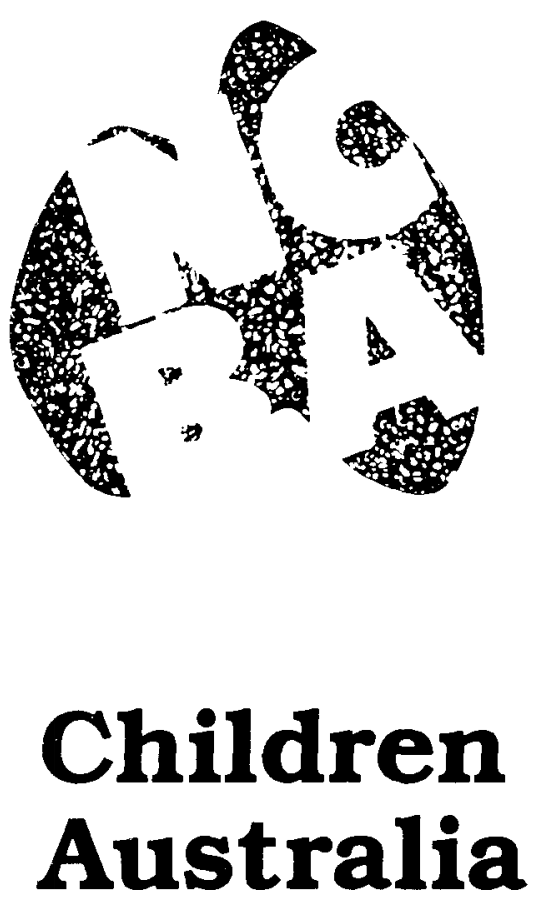

(Quarterly)
In this issue: Special Items from New Zealand

- Kaikomihana mo nga Tamariki -

The Commissioner for Children in New Zealand and the

Children, Young Persons and Their Families Act 1989: . . . . . 4 IAN HASSELL

- Juvenile Justice - New Zealand's family oriented approach $\ldots .7$ ROBERT LUDBROOK

- The Family Group Conference : A new paradigm for making decisions about children and young people . . . . . . 11 GABRIELLE MAXWELL AND ALLISON MORRIS

- Client Participation - Beyond the rhetoric $\ldots \ldots \ldots \ldots \ldots$ PAUL BAN

- Briefing on the Danish Information Campaign on the UN Convention on the Rights of the Child

and

The Child Citizenship Project KIASTEN POULSGAARD

- I love them but they're driving me crazy :

Stress in Mothers of Young Children JILIAN RODD

Recommended Books $\ldots \ldots \ldots \ldots \ldots \ldots \ldots \ldots \ldots$

Chris Goddard is taking a break for this issue. He will be back.

Through Chlldren Australla, the NCA4 provides an opportunity for service providers and rescarchers to report on their work, and for those concerned with chidren and familles to ralse lssues and share their views. The opinions expressed in Chidfren Australla are therefore not necessarlly those of the NCBA. Its Publications Committec or the Editor. 